\title{
ANALYSIS OF IMPACT OF BIOMASS ADDED TO RDF OVERSIZE FRACTION ON PROPERTIES OF BRIQUETTES ${ }^{1}$
}

\author{
Jarosław Frączek, Karolina Słomka-Polonis*, Krzysztof Mudryk, Marek Wróbel, \\ Krzysztof Dziedzic
}

Department of Mechanical Engineering and Agrophysics, University of Agriculture in Krakow

*Corresponding author: e-mail: k.slomka-polonis@ur.krakow.pl

\begin{tabular}{|c|c|}
\hline ARTICLE INFO & ABSTRACT \\
\hline $\begin{array}{l}\text { Article history: } \\
\text { Received: September } 2016 \\
\text { Received in the revised form: } \\
\text { October } 2016 \\
\text { Accepted: November } 2016 \\
\end{array}$ & $\begin{array}{l}\text { The impact of biomass addition to the RDF oversize fraction on } \\
\text { quality parameters obtained from this blend of briquettes produced } \\
\text { under semi-industrial conditions was analysed. For the purposes } \\
\text { related to the experiment four RDF mixtures with fragmented biomass } \\
\text { of common willow Salix viminalis L., differing only with percentage }\end{array}$ \\
\hline $\begin{array}{l}\text { Key words: } \\
\text { solid biofuels, } \\
\text { RDF, } \\
\text { briquette, } \\
\text { biomass, } \\
\text { pressure agglomeration, } \\
\text { quality }\end{array}$ & $\begin{array}{l}\text { participation of base elements, were prepared. The briquetting process } \\
\text { was performed with the use of a semi-industrial briquetting machine at } \\
\text { the determined compaction pressure of } 47 \mathrm{MPa} \text { and a diameter of } \\
\text { a sleeve (and a briquette at the same time) of } 50 \mathrm{~mm} \text {. Selected quality } \\
\text { parameters of produced briquettes were determined, i.e. density, } \\
\text { mechanical strength DU and compression strength. The best } \\
\text { parameters were obtained for briquettes produced from the blend with } \\
\text { a } 50 \% \text { share of willow ( } \rho=843.9 \mathrm{~kg} \cdot \mathrm{m}^{-3} \text {, DU }=86.1 \%, \mathrm{R}_{\mathrm{c}}=0.46 \mathrm{MPa} \text { ). } \\
\text { The lowest parameters were in case of briquettes without biomass } \\
\text { addition. Statistical analysis of research results indicates that biomass } \\
\text { additions to RDF significantly affect the improvement of quality } \\
\text { parameters of the obtained briquettes. }\end{array}$ \\
\hline
\end{tabular}

\section{Introduction}

RDF (refuse-derived fuel) is a solid biofuel produced from municipal waste other than dangerous in order to recover energy, designed for incineration or co-incineration (PN-EN 15357:2011). In Poland RDF is mainly used in co-incineration of waste and co-incineration (cement plants) processes (Malinowski, 2013), but also incurs the interest of energy industry because it includes a great participation of carbon in the composition (40-50\%) (Rejdak and Wasielewski, 2013). It is a material with a varied morphological composition: mainly it is paper, plastic (PET, PP, PVC) as well as gum and textiles (Malinowski, 2013), which in the oversize fraction have irregular shapes and dimensions exceeding $10 \mathrm{~mm}$. $\mathrm{RDF}$ achieves bulk density of $170 \mathrm{~kg} \cdot \mathrm{m}^{-3}$ (Cheng-Shen, 1980) it may also have a varied

\footnotetext{
1 The paper was financed from the funds allotted for scientific research with regard to development and young scientists of the University of Agriculture in Krakow No. BM-4633
} 
moisture (20-50\%). Variability of these parameters causes great impediments during performance of logistic processes (Frączek et al., 2010).

During agglomeration RDF is pressed to the briquette form which often takes a form of a cylinder or a cuboid, which becomes a good quality fuel easier to handle in transport and storage with higher density of energy in comparison to loose material (Liu, 2010; Kaliyan and Morey, 2010). Compaction of materials influences the improvement of numerous parameters of the obtained product, better distribution of mixture components in a briquette/pellet and better durability (Hejft, 2002, Kaliyan and Morey, 2009). The most important parameters from the point of view of logistic processes (transport, storage, reloading, etc.) re compression strength, mechanical strength and density and bulk density (Frączek, 2010). In relation to agglomeration process, determination of the optimal moisture and size distribution of the material which participates in the process is significant (Kriżan, 2015).

There were tests carried out in the Department of Mechanical Engineering and Agrophysics of the University of Agriculture in Krakow. They concerned a possibility of agglomeration of the RDF oversize fraction mixed with biomass. The tests aimed at indication whether the biomass addition will improve the quality parameters of briquettes obtained under semi-industrial conditions and indication of the scope of biomass participation which improves the quality parameters of obtained briquettes.

\section{Material and research methods}

Two types of materials were used in the tests. The main mixture components consisted of RDF from Regional Installation for Municipal Waste Processing [RIPOK] MIKI Sp. $\mathrm{z}$ o.o. in Krakow, which constituted an oversize fraction milled to the theoretical particle size $>10 \mathrm{~mm}$. Energy value of RDF is within 17-18 MJ (Malinowski, 2013).

Biomass is the second material used in the tests. In the course of research, a hypothesis was tested, which said that the biomass additions would positively influence the quality parameters of the obtained briquettes. A classical wood biomass type was selected i.e. fragmented shoots of common willow Salix viminalis $L$. recognized as a basic energy species with good pro-agglomeration parameters (Frączek et al., 2010). Shoots were fragmented to the form of chips and then milled in a hammer mill with a milling screen with meshes diameter of $4 \mathrm{~mm}$. A calorific value of a willow is $18 \mathrm{MJ} \cdot \mathrm{kg}^{-1}$ (Frączek, 2010). Shoots came from the plantation of the Department of Production Engineering and Power Energy of the University of Agriculture in Krakow.

Before the process of compaction was started, a particle size distribution (acc. to PN-EN ISO 17827-2016-07) and moisture content of materials (acc. to PN-EN 15414-3:2011) was determined.

Four blends which differ with a percentage participation of biomass calculated to dry basis of RDF were prepared acc. to the table below (Table 1. Fig.1). Blends were prepared in the blender by PROTECHNIKA in the Laboratory of the Department of Mechanical Engineering and Agrophysics of the University of Agriculture in Krakow.

To produce briquettes from the investigated samples, a briquetting machine PorECOMEC Junior, which constitutes an equipment of the Laboratory was used. It is a hydraulic and piston press with an open compaction chamber with a sleeve diameter of 
Analysis of impact of biomass...

$50 \mathrm{~mm}$. The set working pressure was determined at the maximum compaction scope which is $47 \mathrm{MPa}$. The pressure was controlled by a hydraulic regulator in the machine in order to maintain the same scope for each mixture.

Table 1.

Composition and symbols of investigated blends of RDF and biomass

\begin{tabular}{lccc}
\hline \multirow{2}{*}{ No. } & $\begin{array}{c}\text { Sample } \\
\text { code }\end{array}$ & RDF & Warticipation (\%) \\
\cline { 3 - 4 } 1 & A & 100 & 0 \\
2 & B & 90 & 10 \\
3 & C & 75 & 25 \\
4 & D & 50 & 50 \\
\hline
\end{tabular}

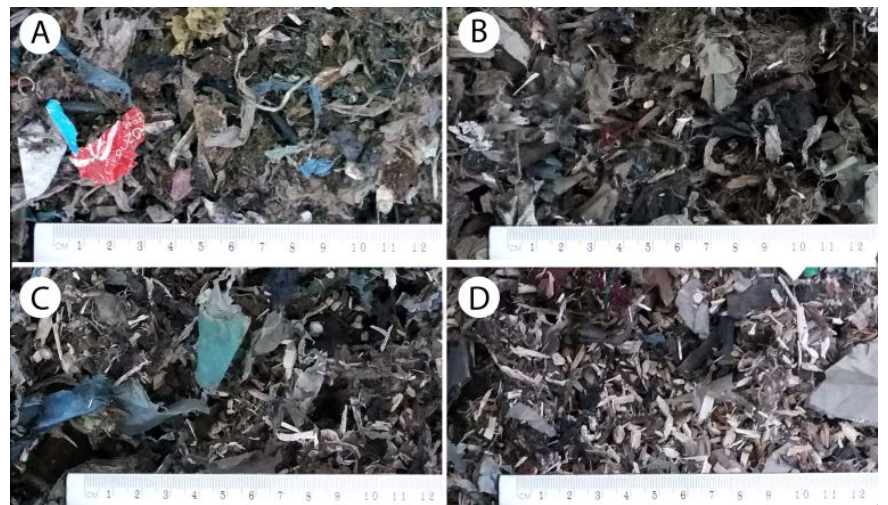

Figure 1. Images of obtained blends - symbols acc. to Table 1

Produced briquettes were seasoned for 24 hours under laboratory conditions. Then, their density $\left(\rho, \mathrm{kg} \cdot \mathrm{m}^{-3}\right)$ was determined based on the formula below:

where:

$$
\rho=\frac{m}{V}
$$

$\mathrm{m}$ - briquette mass, $(\mathrm{kg})$

$\mathrm{V}$ - briquette volume, $\left(\mathrm{m}^{3}\right)$

Determined with the following formula:

$$
\mathrm{V}=\pi \cdot(0.5 \cdot \mathrm{D})^{2} \cdot \mathrm{L}
$$

and results of measurements of their physical properties:

$\mathrm{D}$ - diameter of a briquette, (m)

$\mathrm{L}$ - length of a briquette (m) 
Measurements were carried out with the use of an electronic calliper by LIMIT (140 $\mathrm{mm} \pm 0.01$ ).

Mechanical durability test (DU) was carried out according to the standard PN-EN ISO 17831-22016-02 in a drum tester at the set speed of $21 \mathrm{rpm}$ (duration of the test was 5 minutes). The test was carried out for each type of briquette separately. For calculation of durability parameter of briquettes (DU, \%) the following formula was used (PN-EN ISO 17831-22016-02):

$$
D U=\frac{m_{A}}{m_{E}} \cdot 100 \%
$$

where:

$\mathrm{m}_{\mathrm{A}} \quad$ - weight after testing and sieving, $(\mathrm{kg})$

$\mathrm{m}_{\mathrm{E}} \quad$ - weight before testing and sieving, $(\mathrm{kg})$

Compressive strength of briquettes was calculated acc. to the Brazilian method with the use of a EDZ-20 testing machine. The Brazilian method is a variety of the compression static test, which allows testing different samples including those cylinder - shaped by applying the load along the briquette diameter (Fig. 2). The compression was carried out to the moment the yield strength of a briquette was achieved, registered by momentary stoppage of the dynamometer indicator. Further increase of the compression load (to the moment the scope of a dynamometer of the machine ends) caused flattening of samples.

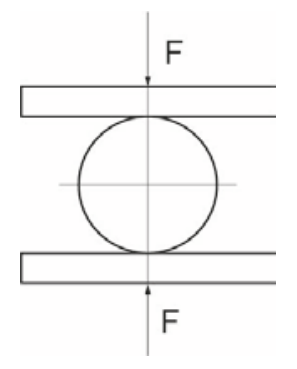

Figure 2. Schematic diagram of loading cylinder-shaped samples during the Brazilian test

Calculations of compression strength (Rc, MPa) were carried out based on the following relation:

where:

$$
R_{C}=\frac{2 \cdot F}{\pi \cdot D \cdot L}
$$

$\mathrm{F}$ - maximum force which loads a briquette, $(\mathrm{N})$

$\mathrm{D}$ - diameter of a briquette, $(\mathrm{m})$

$\mathrm{L}$ - length of a briquette, (m)

For each parameter (density, mechanical durability, compressive strength analysis of variance for single classification calculated in Statistica PL ver 12.5 at the assumed level of significance $\alpha=0.05$ was carried out. Testing ANOVA assumptions was carried out with 
Analysis of impact of biomass...

Levene's test while Sheffe's test was used for testing more precise differences between averages of particular briquette types. Mechanical durability (DU) parameters were an exception. Then, Kruskal-Wallis test was performed which constitutes a non-parametric equivalent of the analysis of variance. An analysis of variance for this parameter was impossible since ANOVA's assumptions concerning normal distribution of a variable were not met.

\section{Discussion on results}

\section{Analysis of quality parameters of RDF and willow}

Particle size distribution was determined with the method of screen analysis based on the standard PN-EN ISO 17827-2016-07. As a result of analysis it may be stated that the RDF used in investigations is a well sorted material. It is composed in approx. $80 \%$ of particles whose dimensions exceeds $8 \mathrm{~mm}$ (Fig. 3A).
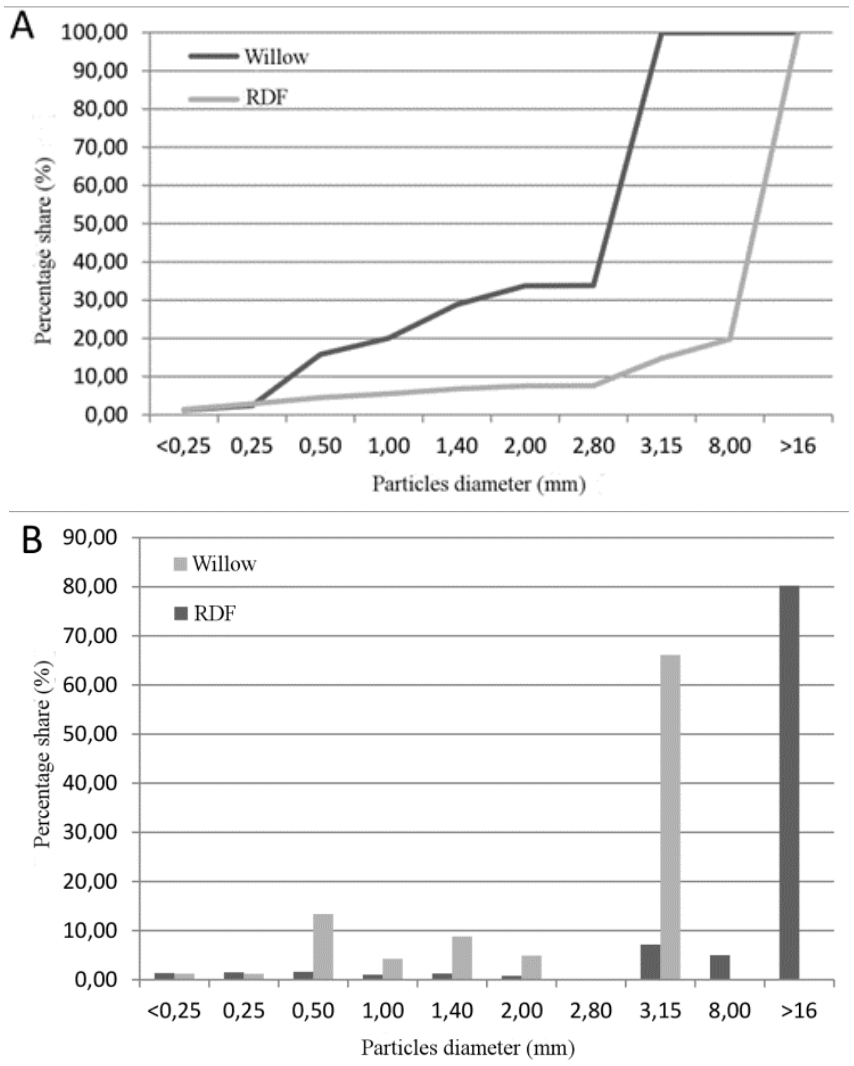

Figure 3. Willow Salix viminalis L. and RDF: A - particle size distribution; B - histogram of particle size distribution 
Biomass in the form of fragmented willow shoots Salix viminalis L. had unsorted composition where particles of the class exceeding $0.50 \mathrm{~mm}$ had greater participation in comparison to RDF (Fig. 3B). The greatest number of $65 \%$ was in case of the fraction particle above $3.15 \mathrm{~mm}$. Dimensional variability of grains in the mixture should allow the best possible filling of empty spaces between the biggest dimensional particles of grains by fine and dust fractions (Guo et al., 2016, Wróbel et al., 2013). Willow as a biomass addition supplements the lacking fine fraction in the RDF-biomass thus it may constitute some kind of a binder and filler which combines bigger RDF particles in the briquetting process (Fig. 3B).

Moisture of blend was determined with the moisture analysis method with the use of drier Elkon type KC 100N based on the standard PN-EN 15414-3:2011. Results of the test proved that moisture of fragmented shoots was $19.51 \%$ and the supplied RDF $-23.73 \%$. Both biomass and alternative fuel required additional drying since too high water content in material may impede compaction of the mixture in the briquetting process at low pressures (Križan, 2015). It is assumed that the optimal content of moisture for biomass allotted for agglomeration should be below $15 \%$ and it would be the best if it was within $8-12 \%$ (Frączek, 2010, Mani et al., 2006). The same range was assumed for RDF. For the needs of the research both materials were dried to the same moisture of $9.5 \%$.

\section{Analysis of strength parameters of briquettes}

As a result of compaction four samples of briquettes which differ with the biomass content were obtained. The average diameter of the obtained briquettes was $53.0 \mathrm{~mm}$ (standard deviation: $\mathrm{SD}=0.083 \mathrm{~cm})$, and the average length was $4.6 \mathrm{~cm}(\mathrm{SD}=0.46 \mathrm{~cm})$. Briquettes had a good compaction (Fig. 4). The most properly-shaped briquettes were obtained at $50 \%$ of willow content in the blend (type D). The remaining briquettes had irregular edges with a visible delamination along with the decrease of the willow content (Fig.4). The worst compactness was reported in the A type briquette where bigger particles of RDF like gum or plastic protruded from the whole (Fig. 4A). It may be related to the absence of addition in the biomass content and too low key pressure for briquetting bigger particles of pure alternative fuel.

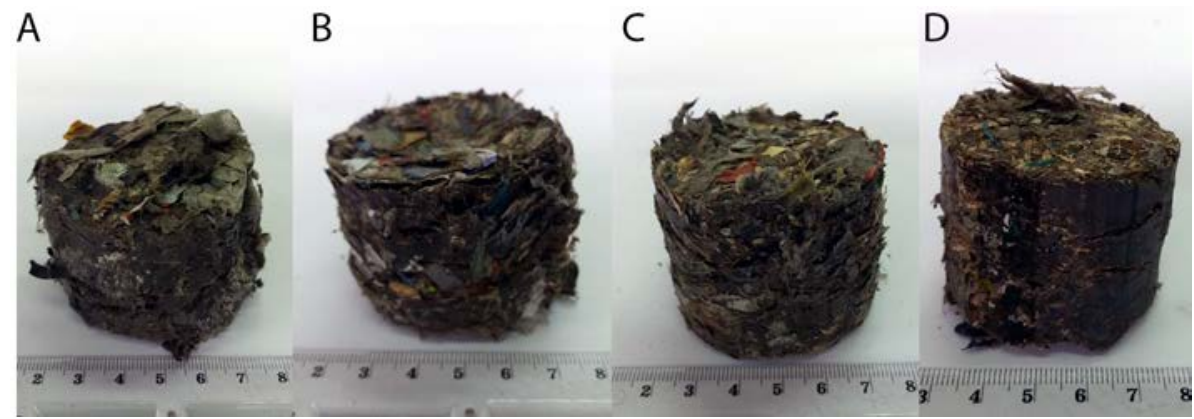

Figure 4. Briquettes obtained in the process of agglomeration in relation to biomass participation in the following composition: $A-0 \%, B-10 \%, C-25 \%, D-50 \%$ 
Analysis of impact of biomass...

Volumetric density was measured after 24 hours of seasoning of briquettes under laboratory conditions $\left(\mathrm{T}=22^{\circ} \mathrm{C}\right)$. The average density of briquette was $764.6 \mathrm{~kg} \cdot \mathrm{m}^{-3}$ $\left(\mathrm{SD}=83.4 \mathrm{~kg} \cdot \mathrm{m}^{-3}\right)$ and differed considerably in relation to the biomass content. The biggest density value of $843.9 \mathrm{~kg} \cdot \mathrm{m}^{-3}$ was in case of briquettes with $50 \%$ content of willow in the composition (type D). The lowest density was measured for briquettes with $100 \%$ of RDF (type A) which was $681.5 \mathrm{~kg} \cdot \mathrm{m}^{-3}$. For the $\mathrm{C}$ type the average density of $779.2 \mathrm{~kg} \cdot \mathrm{m}^{-3}$ was obtained and for type B, density was $763.3 \mathrm{~kg} \cdot \mathrm{m}^{-3}$ (Fig. 5).

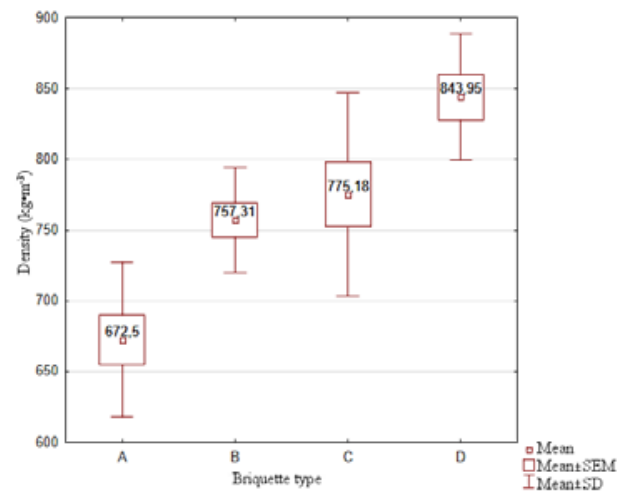

Figure 5. Diagram of average densities of briquettes in relation to the type of briquette

Based on the results of statistical analysis (ANOVA, significance level $\mathrm{p}<0.05$ where $\mathrm{p}<0.0001$, Levene's test $\mathrm{p}=0.0803$ ) one may conclude that the biomass participation has a significant impact on the density of briquettes. Along with the increasing willow content, density of the obtained briquettes rises by approx. $25 \%$. Statistically insignificant difference in the value of the parameters occurs between briquettes B and C (Scheffe test for $\mathrm{p}<0.05$, where $\mathrm{p}=0.908$ ). A conclusion can be made that the range of participation between $10 \%$ and $25 \%$ in the briquette composition does not affect the increase of this parameter. Statistically the highest difference occurs between briquettes B and $\mathrm{C}$ (Scheffe test for $\mathrm{p}<0.05$, where $\mathrm{p}=0.0001$ ).

The highest mechanical durability DU of $86.1 \%$ was in case of D briquettes with $50 \%$ participation of willow. The lowest was in case of briquette produced solely from RDF (A type) where durability was 69.3\% (Fig. 6). Slight increase of the parameter (approx. 4\%) takes place between briquette type B and C, From C briquettes with $25 \%$ participation of biomass, during the test pieces of willow were crumbling. A reverse situation had place in briquettes type A and B where numerous RDF elements fell down. The biggest number of damages took place on the edges which are most affected by the drum test.

In order to verify the variability inside the group, namely the biomass impact in the composition of briquettes on mechanical durability DU, Kruskall-Walis test was carried out. Results of Kruskal-Wallis test for $\mathrm{H}+5.5$. at $\mathrm{p}=0.1386$ allowed rejection of hypothesis $\mathrm{H}_{0}$, that the biomass participation does not differentiate the results of the DU durability test of briquettes. 


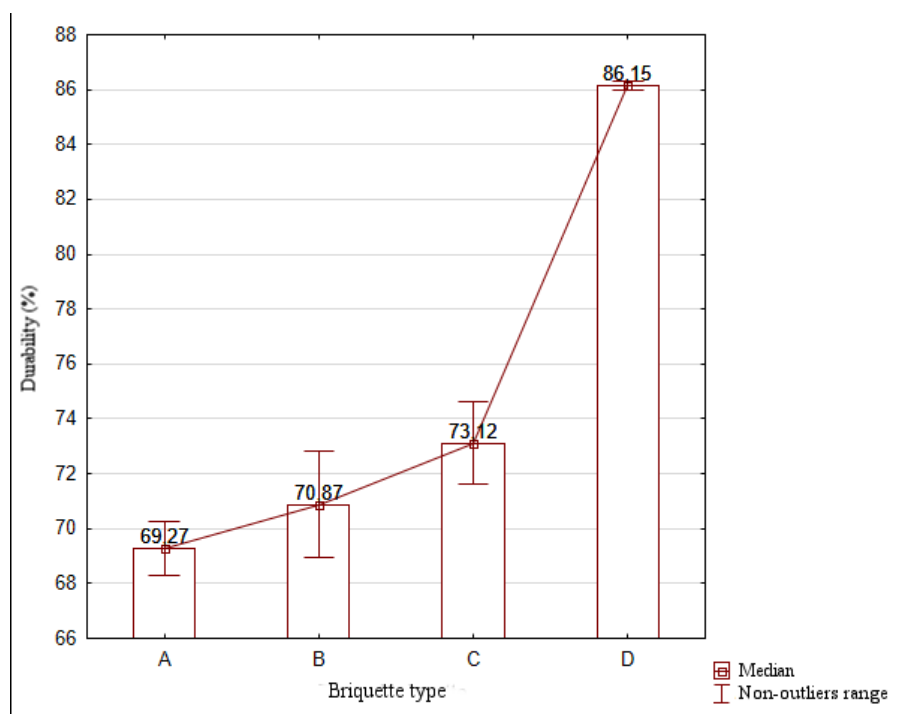

Figure 6. DU durability of briquettes in relation to the type of briquette

In the measurement of mechanical durability DU test mechanisms of destruction which occur during transport and transshipment are simulated. Under such conditions briquettes' strength to crushing, friction and vibrations and strokes is investigated. The obtained results of DU durability rather prove a low quality of briquettes. It may result from the presence of big particles of RDF (more than $8 \mathrm{~mm}$ ) in the composition of the blend and low compaction pressure (47 MPa), which made their good bonding impossible.

The average maximum load as $1265.42 \mathrm{~N}(\mathrm{SD}=502.49 \mathrm{~N})$. The highest average value $\mathrm{F}=1547.5 \mathrm{~N}$ was registered for briquettes $\mathrm{D}$ type (Fig. 7A) while the lowest for A briquettes, where F=310.0 N. During the test briquettes A and B type showed properties of plastic material under the F force load, more or less visible yield point was noticed. After the load was removed these briquettes, did not fall apart, but they maintained a flat form. Along with the increase of biomass participation, briquettes showed more features of elastic materials. During the influence of the compression force in $\mathrm{D}$ type briquettes visible fissures along a diameter were created. The average strength to compression of investigated briquettes was $0.23 \mathrm{MPa}(\mathrm{SD}=0.14 \mathrm{MPa})$. The highest compression strength $\mathrm{Rc}$ of $0.46 \mathrm{MPa}$ was in case of briquettes with $50 \%$ biomass content in the composition (type D). The lowest was registered in briquettes type A, which was $0.08 \mathrm{MPa}$ (Fig. 7B).

Based on the results of statistical analysis (ANOVA, significance level $\mathrm{p}<0.05$ where $\mathrm{p}<0.0001$, Lavene's test $\mathrm{p}=0.0619$ ) one may conclude that the biomass participation has a significant impact on the value of force which destroys briquettes and thus to the compression strength. Along with the increasing content of willow in the blend, strength of briquettes raises. Scheffe test (for $\mathrm{p}<0.05$ ) indicates statistically significant differences between the types of briquettes where the biggest is between briquettes $\mathrm{A}$ and $\mathrm{D}$ (Scheffe's test for $\mathrm{p}<0.05$, where $\mathrm{p}<0.0001$ ), while the lowest between briquettes B and C (Scheffe's test for $\mathrm{p}<0.05$, where $\mathrm{p}=0.0304$ ). 
Analysis of impact of biomass...
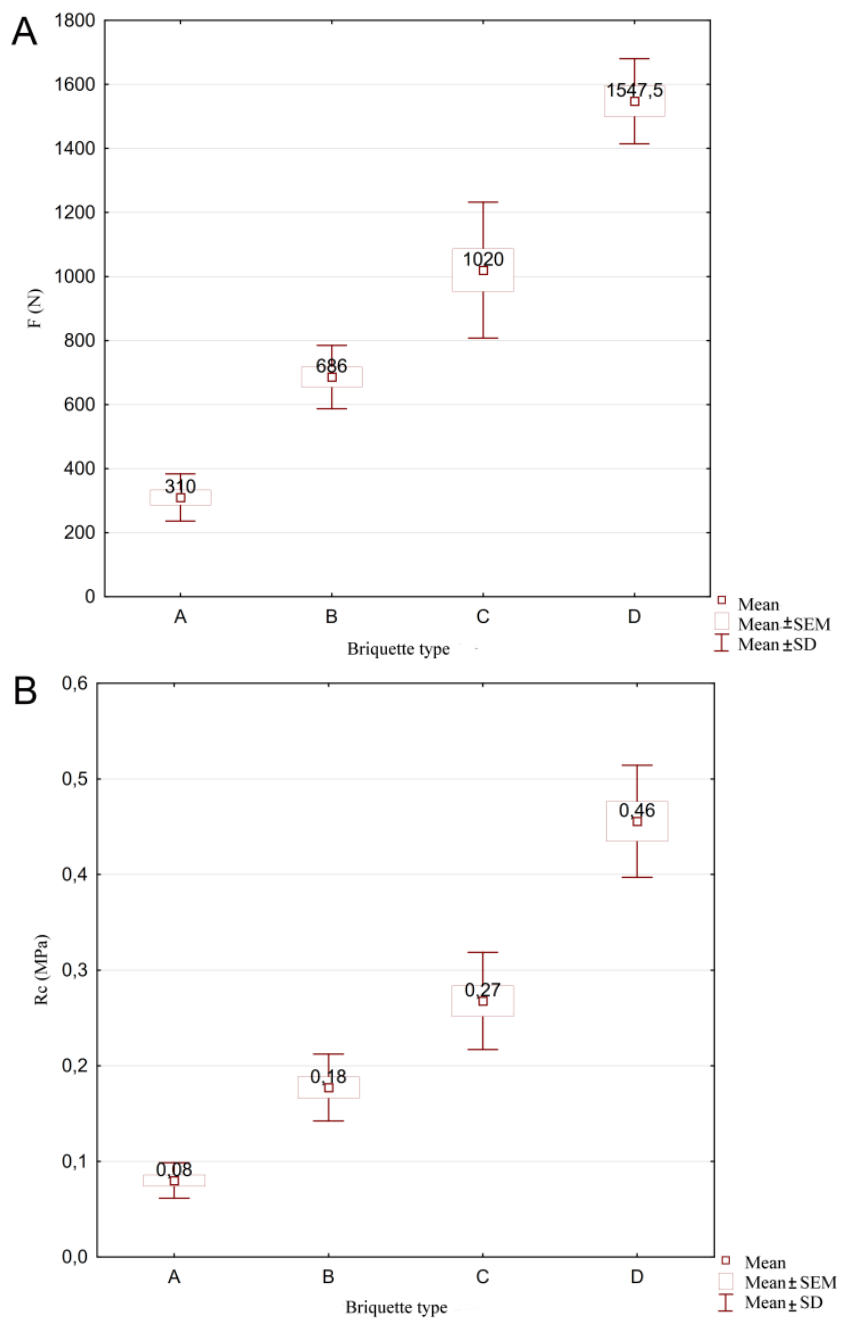

Figure 7. Brazilian test: A - Diagram of average destroying load $F(N)$ in relation to the type of briquettes; $B$ - diagram of average compression strength $R c(M P a)$ in relation to the type of briquettes.

\section{Conclusion}

RDF of the oversize fraction is a difficult material in case of the process of agglomeration due to a varied elementary composition of fuel and dimension and shape of elements (above $10 \mathrm{~mm}$ ). Briquettes produced from pure RDF (A type) delaminated and had irregular shapes. Their parameters are considerably worse than briquettes mixed with a willow. 
Biomass additions marked its advantageous impact on the properties of the produced fuel and on the behaviour of the briquette shape. The highest parameters were obtained for briquettes $\mathrm{D}$ type to $50 \%$ of biomass content in the composition. These briquettes had the highest density which was at the average of $843.9 \mathrm{~kg} \cdot \mathrm{m}^{-3}$, the highest mechanical durability DU in the drum test of $86.14 \%$ and the highest value of compression strength Rc in the Brazilian test which was $0.46 \mathrm{MPa}$. The worst parameters were obtained for the A type briquettes produced from the RDF fuel. If one considered the standard PN-EN ISO 17225 "Solid biofuels - Fuel specifications and classes" classifying products, in relation to the specific density (above $0.80 \mathrm{~kg} \cdot \mathrm{dm}^{-3}$ ), D type briquette with $50 \%$ willow content would be good for commercial purposes. However, this standard does not classify as for now, RDF fuel mixtures with biomass and providing strength parameters is also not obligatory. According to Frączek (2010) providing only values of the briquette density is not enough to decide on the fuel usefulness. If the standard PN-EN ISO 17225 included this mixture, then based on the results of this research, briquettes with insufficient strength, which may fall apart during transport, would be good for commercial purposes (Fig. 8).

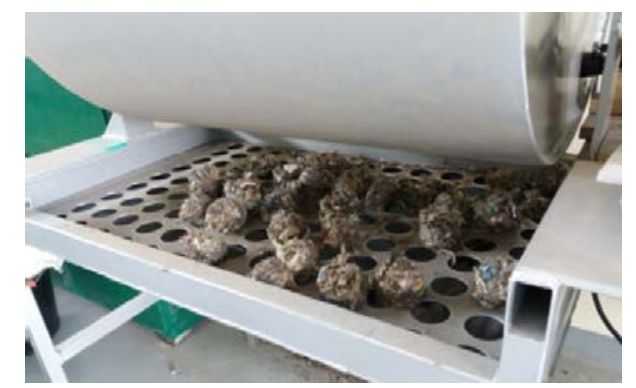

Figure 8. B type briquettes after the DU durability (image of a screen with meshes diameter of $35 \mathrm{~mm}$ under the drum tester).

In the provided technological system under low pressure conditions without initial preparation of material, the obtained research results provide bases for carrying out a more extensive analysis of the agglomeration process of the RDF mixture with biomass.

There are works carried out on construction of machines which enable extension of the analysis on the briquetting process in the semi-industrial scale in the Department of Mechanical Engineering and Agrophysics of the University of Agriculture in Krakow. It will allow starting the second stage of research, namely, carrying out an analysis of the impact of variable temperature and pressure on briquetting of the mixture of the oversize fraction of RDF and biomass.

\section{Conclusions}

1. Biomass participation in the RDF briquettes composition statistically significantly influences the improvement of quality parameters of briquettes. Along with the increase of the percentage participation of biomass in the composition, the average density of briquettes, DU durability and compression strength, increase. 
Analysis of impact of biomass...

2. Increase of biomass participation in the composition of mixtures from 0 to $50 \%$ caused the increase of the average density of briquettes from 672.5 to $853.52 \mathrm{~kg} \cdot \mathrm{m}^{-3}$ (relative difference approx. 20\%); increase of the average DU durability of briquette from 69.3 to $86.2 \%$ (relative difference of approx. 19\%); increase of the average compression strength.

3. The highest results of experiments were obtained for briquettes with $50 \%$ biomass participation in the composition of mixtures $\rho=843.9 \mathrm{~kg} \cdot \mathrm{m}^{-3}$, DU durability $=86.14 \%$, Rc strength $=0.46 \mathrm{MPa}$.

\section{References}

Beckmann, M., Ncube, S. (2007). Characterisation of Refuse Derived Fuels (RDF) in Reference to the Fuel Technical Properties. In: Proceedings of the International Conference on Incineration and Thermal Treatment Technologies - IT3, 14.05.-18.05.2007, Phoenix (USA). ISBN 9780923204822.

Frączek, J. (red.) (2010). Optymalizacja procesu produkcji paliw kompaktowanych wytwarzanych z roślin energetycznych. PTIR, Kraków. ISBN 978-83-917053-9-1.

Frączek, J., Mudryk, K., Wróbel, M. (2010). Nakłady energetyczne w procesie brykietowania wierzby Salix viminalis L. Inżynieria Rolnicza, 3(121), 45-52.

Guo, L., Tabil, L. G., Wang, D., Wang, G. (2016). Influence of moisture content and hammer mill screen size on the physical quality of barley, oat, canola and wheat straw briquettes. Biomass \& Bioenergy 94, 201-208.

Hejft, R. (2002). Ciśnieniowa aglomeracja materiałów roślinnych. Wyd. i Zakład Poligrafii Instytutu Technologii Eksploatacji, Radom. ISBN 83-7204-251-9.

Kalyan, N., Morey, R. V. (2009). Factors affecting strengh and durability of desified biomass product. Biomass \& Bioenergy, 33, 337-359.

Kalyan, N., Morey, R.V. (2010). Natural binders and solid bridge type binding mechanisms in briquettes and pellets made from corn stover and switchgrass. Bioresource Technology 101, 1082-1090.

Križan, P. (2015). The Densification Process of Wood Waste. De Gruyter Open Ltd, Warsaw/Berlin. ISBN 978-3-11-044001-0.

Liu, Y. (2010). Modelling and Characterisation of the Pyrolysis of Secondary Refuse Fuel Briquettes and Biomass Materials. Ph.D. Thesis Faculty of Advanced Technology University of Glamorgan, Cardiff. ISNI: 0000000401252023.

Malinowski, M. (2013). Selected Properties of alternative fuel manufactured from minicipal solid waste. Infrastructure and Ecology of Rural Areas, 2/IV, Polska Akademia Nauk, Oddział w Krakowie, 125-139.

Mani, S., Tabil, L. G., Sokhansaj, S. (2006). Effects of compressive force, particle size and moisture content on mechanical properties of biomass pellets from grasses. Biomass \& Bioenergy, 30, 648-654.

PN-EN 15414-3:2011. Stałe paliwa wtórne. Oznaczanie zawartości wilgoci metodą suszarkową Część 3: Wilgoć w ogólnej próbce analityczne.

PN-EN 15357:2011 - Stałe paliwa wtórne - Terminologia, definicje i określenia.

PN-EN ISO 17827-2016-07. Biopaliwa stałe. Oznaczanie składu ziarnowego paliw niesprasowanych - Cześć 1.

PN-EN ISO 17831-22016-02. Biopaliwa stałe. Oznaczanie wytrzymałości mechanicznej brykietów i peletów. Część 2: Brykiety. 
Rejdak, M., Wasielewski, R. (2013). Industrial tests of co-pyrolysis solid recovered fuels (SRF) and hard coal. Archives of Waste Management and Environmental Procection, vol. 15, issue 1, 29-36.

Wróbel, M., Frączek, J., Francik, S., Slipek, Z., Mudryk, K. (2013). Influence of degree of fragmentation on chosen quality parameters of briquette made from biomass of cup plant Silphium perfoliatum L. Engineering for Rural Development Jelgava, Available at: http://tf.llu.lv/conference/proceedings2013/Papers/121_Wrobel_M.pdf.

\section{ANALIZA WPLYWU DODATKU BIOMASY DO FRAKCJI NADSITOWEJ RDF NA WLASNOŚCI UZYSKANYCH \\ BRYKIETÓW}

Streszczenie. Przedstawiono analizę wpływu dodatku biomasy do frakcji nadsitowej RDF na parametry jakościowe uzyskanych $\mathrm{z}$ tej mieszanki brykietów, utworzonych $\mathrm{w}$ warunkach półprzemysłowych. Na potrzeby doświadczenia utworzono cztery mieszanki RDF wraz z rozdrobnioną biomasą wierzby wiciowej Salix viminalis $L$., różniące się udziałem procentowym składników bazowych. Proces brykietowania wykonano przy użyciu półprzemysłowej brykieciarki przy ustalonym ciśnieniu zagęszczania $47 \mathrm{MPa}$ i średnicy tulei (a tym samym brykietu) $50 \mathrm{~mm}$. Określono wybrane parametry jakościowe utworzonych brykietów tj.: gęstość właściwą, trwałości mechaniczną DU i wytrzymałość na ściskanie. Najlepsze parametry uzyskano dla brykietów wytworzonych z mieszanki z 50\% udziałem wierzby $\left(\rho=843,9 \mathrm{~kg} \cdot \mathrm{m}^{-3}\right.$, DU $\left.=86,1 \%, \mathrm{R}_{\mathrm{c}}=0,46 \mathrm{MPa}\right)$. Najniższe parametry uzyskały brykiety bez dodatku biomasy. Analiza statystyczna wyników badań wskazuje, że dodatek biomasy do RDF'u istotnie wpływa na poprawę parametrów jakościowych uzyskanych brykietów.

Słowa kluczowe: biopaliwa stałe, RDF, brykiet, biomasa, aglomeracja ciśnieniowa, jakość 